\title{
The use of polyaluminium chloride as a restoration measure to improve water quality in tropical shallow lakes
}

\author{
O uso de cloreto de polialumínio como medida de restauração da qualidade da água \\ em lagos rasos tropicais
}

Fabiana Araújo ${ }^{1 *}$, Hélio Rodrigues dos Santos ${ }^{2}$, Vanessa Becker ${ }^{2}$ and José Luiz Attayde

${ }^{1}$ Programa de Pós-graduaçáo em Ecologia, Departamento de Ecologia, Centro de Biociências, Universidade Federal do Rio Grande do Norte - UFRN, Av. Salgado Filho, 3000,

CEP 59078-970, Natal, RN, Brasil

${ }^{2}$ Departamento de Engenharia Civil, Centro de Tecnologia, Universidade Federal do Rio Grande do Norte - UFRN, Av. Salgado Filho, 3000, CEP 59078-970, Natal, RN, Brasil

${ }^{3}$ Departamento de Ecologia, Centro de Biociências, Universidade Federal do Rio Grande do Norte - UFRN, Av. Salgado Filho, 3000, CEP 59078-970, Natal, RN, Brasil

*e-mail: fabianabio@gmail.com

Cite as: Araújo, F. et al. The use of polyaluminium chloride as a restoration measure to improve water quality in tropical shallow lakes. Acta Limnologica Brasiliensia, 2018, vol. 30, e109.

Abstract: Aim: The aim of this study was to evaluate the performance of the coagulant Polyaluminium chloride (PAC) in water quality improvement of six eutrophic shallow lakes in Brazilian semiarid region. Methods: We evaluated the effect of PAC in turbidity, humic substances $\left(\mathrm{UV}_{254}\right)$, total phosphorus and chlorophyll- $a$ concentration through laboratory jar tests. Results: The results showed that PAC had a good performance in reducing total phosphorus concentrations and turbidity, with a reduced efficiency in removing chlorophyll- $a$ and humic substances by sedimentation of flocks formed. Conclusions: Addition of PAC is a potential tool for water quality improvement of eutrophic shallow lakes in Brazilian semiarid region but its efficiency depends on the $\mathrm{pH}$ and particulate and dissolved organic matter concentration in the lake or reservoir water.

Keywords: coagulation; phosphorus removal; turbidity removal; lake restoration; semiarid region.

Resumo: Objetivo: O objetivo deste estudo foi avaliar a performance do coagulante cloreto de polialumínio (PAC) na melhoria da qualidade da água de seis lagos rasos eutróficos na região semiárida brasileira. Métodos: Nós avaliamos o efeito do PAC na turbidez, substâncias húmicas $\left(\mathrm{UV}_{254}\right)$ e concentraçóes de fósforo total e clorofila- $a$. Resultados: Os resultados mostraram que PAC possui uma boa performance em reduzir as concentraçôes de fósforo total e turbidez, com uma eficiência reduzida em remover clorofila-a e substâncias húmicas, através da sedimentação dos flocos formados. Conclusóes: A adição de PAC se apresenta como uma potencial estratégia para melhoria da qualidade da água de lagos rasos eutrófico na região semiárida brasileira, porém sua eficiência é dependente do pH e da concentração da matéria orgânica particulada e dissolvida na água do reservatório ou lago.

Palavras-chave: coagulação; remoção de fósforo; remoção de turbidez; restauração de lagos; região semiárida. 


\section{Introduction}

The internal phosphorus (P) loading from $\mathrm{P}$-rich sediments is considered the major cause of delay in shallow lake restoration after reduction of external P loading (Søndergaard et al., 2000, 2003). As a result, several chemical methods have been applied to control P internal loading worldwide (Welch \& Cooke, 1999; Reitzel et al., 2005; Spears et al., 2013). The most used technique is the precipitation and inactivation of phosphorus by coagulants, especially those based on aluminium (Al) (Cooke et al., 2005). When Al salts are added to water, $\mathrm{Al}^{+3}$ preferable reacts with $\mathrm{PO}_{4}^{-3}$ and forms a precipitate, which can be removed from the water column after coagulation, flocculation and subsequent sedimentation. Besides this, coagulation and flocculation are also able to remove inorganic and organic suspended particles (Jiang \& Graham, 1998), turbidity and total phosphorus from the water column. Among the Al-based coagulants, the aluminium sulphate $\left(\mathrm{Al}_{2}\left(\mathrm{SO}_{4}\right)_{3}\right)$, or alum, is the most commonly used chemical in lake restoration. Its effectiveness in removing phosphorus has been reported in several laboratory and whole-lake experiments (Welch \& Schrieve, 1994; Van Hullebusch et al., 2002; Lewandowski et al., 2003). However alum may result in high concentration of residual $\mathrm{Al}$ and is strongly affected by temperature (Van Benschoten \& Edzwald, 1990) and $\mathrm{pH}$.

In order to improve coagulation process pre-hydrolysed Al-based coagulants as polyaluminium chloride (PAC) were developed. Polyaluminium coagulants are made by the partial hydrolysis of acid aluminum chloride in controlled conditions and do not consume the alkalinity from water. Thus, PAC has a superior coagulation performance than alum due to its wider $\mathrm{pH}$ range, lower sensitivity to low water temperature, lower doses required and lower residual $\mathrm{Al}$ concentrations (Jiang \& Graham, 1998). A number of laboratory and field experimental studies has shown the superior performance of PAC in both turbidity and phosphorus removal (Reitzel et al., 2003; Gao et al., 2005; Chen \& Luan, 2010; De Julio et al., 2010; Yang et al., 2010; Noyma et al., 2015; Araújo et al., 2016). The application of PAC in whole lake experiments has shown its efficacy in removing phosphorus from the water column (Reitzel et al., 2005; Lopata \& Gawrońska, 2008; Egemose et al., 2011; Jančula \& Maršálek, 2012) and turbidity

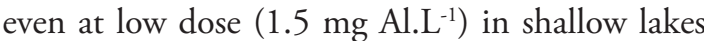
(Van Hullebusch et al., 2002), and it has been suggested as a lake restoration measure.
Coagulation-flocculation process is directly affected by the presence of particles and dissolved organic matter present in the water (Edzwald, 1993) and also by water chemistry ( $\mathrm{pH}$ and alkalinity) (Pernitsky \& Edzwald, 2006). PAC was developed to depress alkalinity consumption but its efficiency is $\mathrm{pH}$ dependent. The effectiveness of PAC coagulation is affected by aluminium speciation after its application in water which in turns is determined by $\mathrm{pH}$ (Edzwald, 1993). At $\mathrm{pH}$ of 6.0-7.0 the chemical species of hydrolyzed aluminium are highly charged and very efficient in particles and dissolved organic matter removal (Yan et al., 2008a, b). Algae also can affect coagulation due to characteristics such as morphology, motility, surface charge and algogenic organic matter (Henderson et al., 2008a, b, 2010).

In the tropical semi-arid region of Northeastern Brazil there are thousands of eutrophic man-made lakes are used for water supply despite of constant blooms of toxic cyanobacteria. Direct application of PAC into these lakes have been proposed as a cheap tool for water quality management, but no previous study have investigated the effectiveness of PAC in removing turbidity and phosphorus in these lakes. The aim of this study was to evaluate the performance of polyaluminium chloride in water quality improvement of six eutrophic shallow lakes in Brazilian semiarid region through laboratory jar tests. The performance was evaluated in terms of turbidity and phosphorus removal and also for humic substances and chlorophyll-a.

\section{Material and Methods}

\subsection{Raw water}

Water samples were collected from the pelagic region of six reservoirs in Rio Grande do Norte State, Brazil: Gargalheiras, Passagem das Traíras, Boqueiráo, Dourados, Cruzeta and Timbaúba reservoir. The samples were kept in laboratory, at room temperature, by up to $48 \mathrm{~h}$ before the start of the experiments. The turbidity (NTU; Turbidimeter AP2000), concentrations of chlorophyll- $a$ (Jespersen \& Christoffersen, 1988) and concentrations of total phosphorus (Valderrama, 1981; Murphy \& Riley, 1962) were measured to caracterize the raw water.

\subsection{Coagulant dose}

The coagulant used were polyalumnium chloride (PAC; PANFLOC TE1018 - Pan-Americana S/A), as liquid (16-18\% of $\mathrm{Al}_{2} \mathrm{O}_{3}$ ). A stock solution was prepared at a concentration of $1 \mathrm{~g} \mathrm{Al} \cdot \mathrm{L}^{-1}$. Six doses

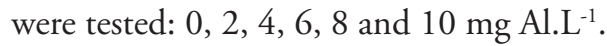




\subsection{Jar test}

Standard jar test equipment ( 6 probes with two liters capacity each) was used in a conventional assay method: rapid mixing, flocculation and sedimentation (Table 1). Two liters of raw water were transferred to each $2 \mathrm{~L}$ probes. The coagulant was dosed just after starting the rapid mixing step. All experiments were carried out in room temperature at $24^{\circ} \mathrm{C}\left( \pm 1^{\circ}\right)$. After sedimentation time, samples were collected from $7 \mathrm{~cm}$ below the water surface for subsequent analysis. Turbidity, $\mathrm{pH}$, temperature and total phosphorus were measured in the collected sample. A subsample was filtrated (1.2 $\mu \mathrm{m}$ membrane) to measure chlorophyll- $a$ and also $\mathrm{UV}_{254}$ absorbance $(1 \mathrm{~cm}$ quartz cell; Shimadzu spectrophotometer). $\mathrm{UV}_{254}$ was measured to indicate the content of dissolved organic matter (DOM), mainly as humic substances (Leenheer \& Croué, 2003).

\subsection{Data analysis}

PAC performance was evaluated in terms of removal efficiency (R.E.) by sedimentation of flocks, as percentage reduction of chlorophyll- $a$ and total phophorus concentration, turbidity and $\mathrm{UV}_{254}$ absorbance. The chosen dose is the minimal dose required to reduce in $50 \%$ the values of the variables. We evaluated correlations between the PAC performance at the chosen dose and initial chlorophyll- $a$ concentration and $\mathrm{pH}$ using Spearman correlation test $(r ; \alpha<0.05)$.

\section{Results}

\subsection{Initial conditions of raw water}

All reservoirs were classified as eutrophic according to Thornton \& Rast (1993) as they had chlorophyll- $a$ concentrations $>15 \mu \mathrm{g} \mathrm{L}^{-1}$ and total

Table 1. Jar test conditions.

\begin{tabular}{cccc}
\hline Step & Rotation & Time & Gradient \\
\hline Rapid mixing & 300 & $30 \mathrm{~s}$ & $600 \mathrm{~s}^{-1}$ \\
Flocculation & 30 & $20 \mathrm{~min}$ & $20 \mathrm{~s}^{-1}$ \\
Sedimentation & 0 & $30 \mathrm{~min}$ & $3 \mathrm{~m} \mathrm{day}^{-1}$ \\
\hline
\end{tabular}

phosphorus concentration $>50 \mu \mathrm{g} \mathrm{L}^{-1}$ (Table 2). Gargalheiras and Passagem das Traíras showed the highest chlorophyll- $a$ and total phosphorus concentrations.

\subsection{PAC performance}

The $\mathrm{pH}$ decreased as PAC dose increased with the coagulant application but final $\mathrm{pH}$ was always above 6.5 (data not shown). In general, the removal efficiency increased sharphly from

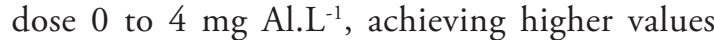

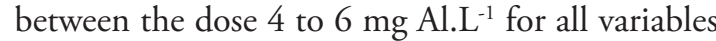
(Figure 1). Then, two situations were observed: the increasing in the dose did not cause an increasing in the efficiency for total phosphorus, chlorophyll- $a$ and turbidity removal; or the efficiency increased continuously with the increasing of the $\mathrm{Al}$ dose for $\mathrm{UV}_{254}$ removal where only the highest doses showed an efficiency above $50 \%$. None Al dose was efficient in removing at least $50 \%$ of total phosphorus, turbidity, $\mathrm{UV}_{254}$ and chlorophyll- $a$ for Passagem das Traíras reservoir (Figure 1). The increasing in $\mathrm{Al}$ dose

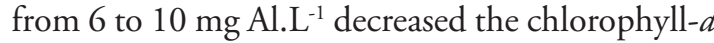
removal efficiency for Cruzeta and Passagem das Traíras reservoirs (Figure 1d).

For most reservoirs, the minimal dose required to reduce in at least $50 \%$ the concentrations of the

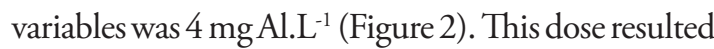
in turbidity values $\leq 10 \mathrm{NTU}$, total phosphorus concentration $\leq 50 \mu \mathrm{g} \cdot \mathrm{L}^{-1}$ and chlorophyll-a concentration $\leq 15 \mu \mathrm{g} . \mathrm{L}^{-1}$ for Cruzeta, Timabúba e Dourados reservoirs. Boqueirão reservoir water achieved a turbidity of 10.3 NTU and had total phophorus concentration reduced to values below $50 \mu \mathrm{g} \mathrm{L}^{-1}$ but clorophyll-a concentration remained above $15 \mu \mathrm{g} . \mathrm{L}^{-1}$. The total phosphorus, turbidity and

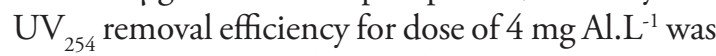
significantly negatively correlated with the initial chlorophyll-a concentration and $\mathrm{pH}$ (Figure 3). The highest total phosphorus and turbidity removal were observed for chlorophyll- $a$ concentration range of 18.8-39.9 $\mu \mathrm{g} . \mathrm{L}^{-1}$ and $\mathrm{pH}$ range of 6.8-7.9. The highest $\mathrm{UV}_{254}$ removal was observed for the same $\mathrm{pH}$ range but for even lower chlorophyll- $a$ concentration (18.8-27.3 $\left.\mu \mathrm{g} \cdot \mathrm{L}^{-1}\right)$.

Table 2. pH, Turbidity, absorbance at UV $254 \mathrm{~nm}$, total phosphorus (TP) and chlorophyll- $a$ concentrations in raw water used for jar tests.

\begin{tabular}{cccccc}
\hline Reservoir & $\mathbf{p H}$ & Turbidity (NTU) & UV254 & TP $\left(\boldsymbol{\mu g ~ \mathbf { g } ^ { - 1 }}\right)$ & $\mathbf{C h l}^{-\mathbf{a}\left(\boldsymbol{\mu g ~ L ^ { - 1 }}\right)}$ \\
\hline Cruzeta & 7.95 & 11.8 & 0.263 & 127.00 & 18.82 \\
Timbaúba & 6.85 & 21.4 & 0.327 & 89.50 & 27.30 \\
Dourados & 7.35 & 20.8 & 0.402 & 153.67 & 39.93 \\
Boqueirão & 8.43 & 24.2 & 0.264 & 62.00 & 46.10 \\
Passagem das Traíras & 8.46 & 35.0 & 0.509 & 163.75 & 89.79 \\
Gargalheiras & 8.66 & 15.5 & 0.401 & 189.50 & 90.83 \\
\hline
\end{tabular}



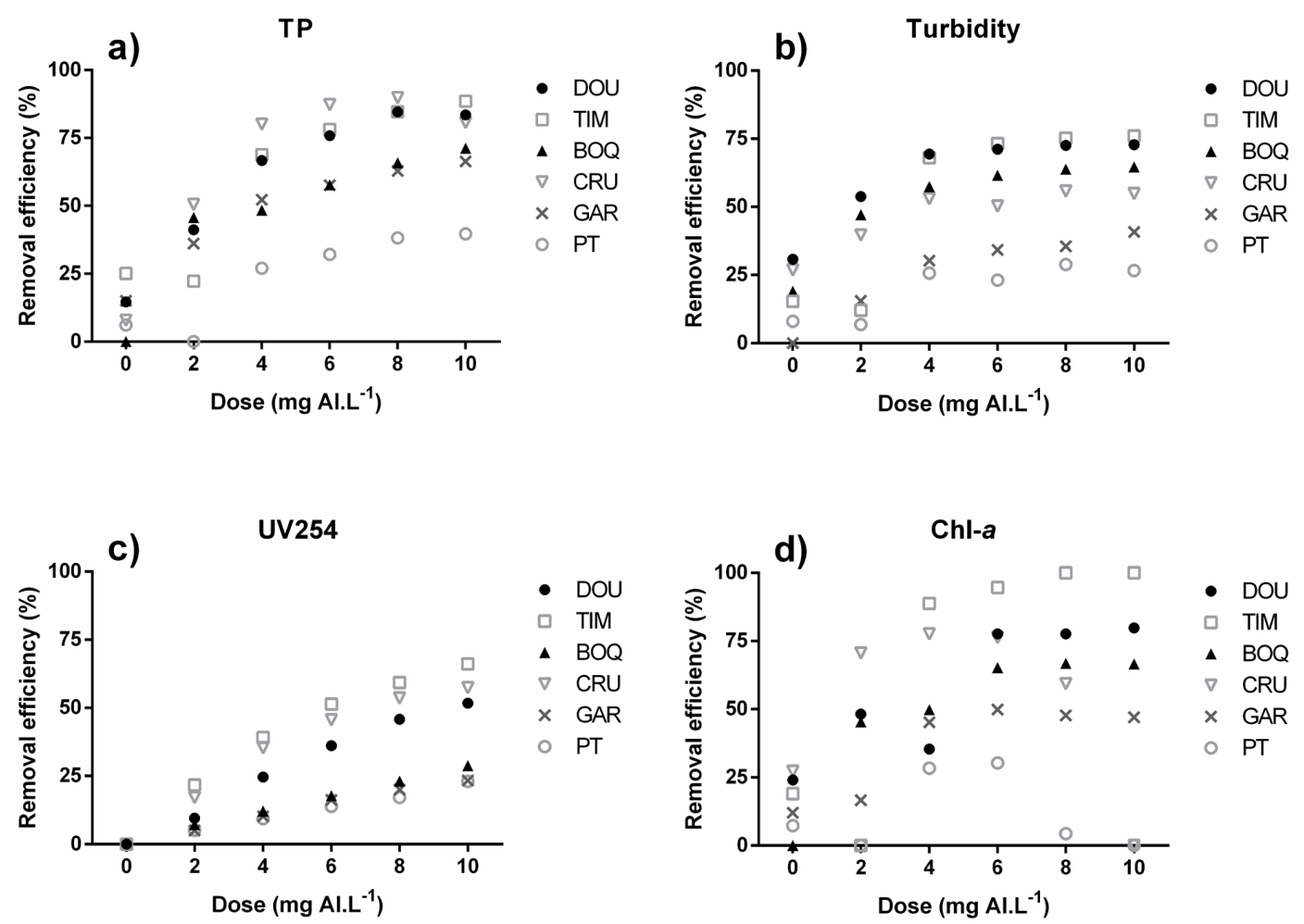

Figure 1. Removal efficiency (\%) for total phosphorus (TP), turbidity, humic substances $\left(\mathrm{UV}_{254}\right)$ and chlorophyll-a (Chl-a) in raw water from Dourados (DOU), Timbaúba (TIM), Boqueirão (BOQ), Cruzeta (CRU), Gargalheiras (GAR) and Passagem das Traíras (PT) reservoirs, after coagulation-flocculation with different concentrations of aluminium $\left(0,2,4,6,8\right.$ and $\left.10 \mathrm{mg} \mathrm{Al} \mathrm{L}^{-1}\right)$ and 30 minutes of sedimentation.

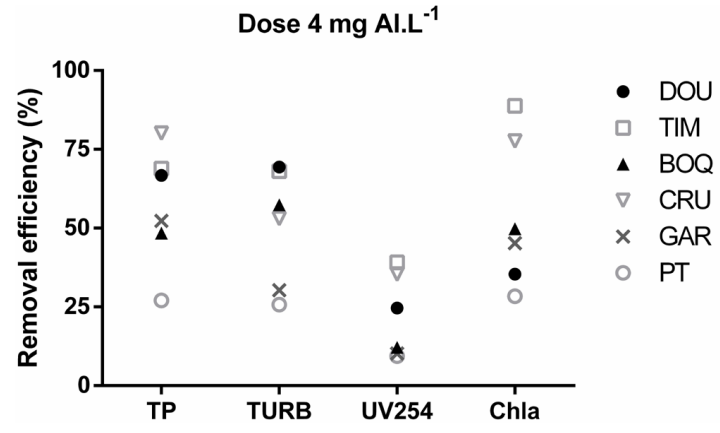

Figure 2. Removal efficiency (\%) for total phosphorus (TP), turbidity (TURB), humic substances $\left(\mathrm{UV}_{254}\right)$ and chlorophyll-a (Chl-a) in raw water from Dourados (DOU), Timbaúba (TIM), Boqueirão (BOQ), Cruzeta (CRU), Gargalheiras (GAR) and Passagem das Traíras (PT) reservoirs, after coagulation-flocculation with the dose of $4 \mathrm{mg} \mathrm{Al} \mathrm{L}^{-1}$ and 30 minutes of sedimentation.

\section{Discussion}

In general, PAC showed good performance in removing total phosphorus concentrations and turbidity, but its efficiency was affected by chlorophyll- $a$ and humic substances concentration. We suggested that $4 \mathrm{mg} \mathrm{Al} . \mathrm{L}^{-1}$ is the best dose (better cost-benefit) to be applied in most of reservoirs tested. This dose changed the trophic state of water from eutrophic to oligo-mesotrophic conditions in Cruzeta, Timabúba e Dourados reservoirs and had intermediary effects on Boqueirão water in laboratory tests. The efficiency in total phosphorus removal is reported for in-lake PAC application (Reitzel et al., 2005; Lopata \& Gawrońska, 2008; Egemose et al., 2011; Jančula \& Maršálek, 2012). However, PAC showed a low efficiency in improving water quality in Gargalheiras and Passagem das Traíras reservoirs.

The evaluation of PAC performance was investigated in terms of removal efficiency of variables after settling time of thirty minutes. Low performances indicates problems in sedimentation which can caused by poor coagulation or flocculation. High chlorophyll-a concentration, $\mathrm{pH}$ and humic substances in initial conditions probably are the causes of the low efficiency removal of flocks formed by PAC in Gargalheiras and Passagem das Traíras water. Our correlations showed that total phosphorus, turbidity and $\mathrm{UV}_{254}$ removal efficiency are correlated with higher values in initial $\mathrm{pH}$ and chlorophyll-a concentrations. Initial $\mathrm{pH}$ 

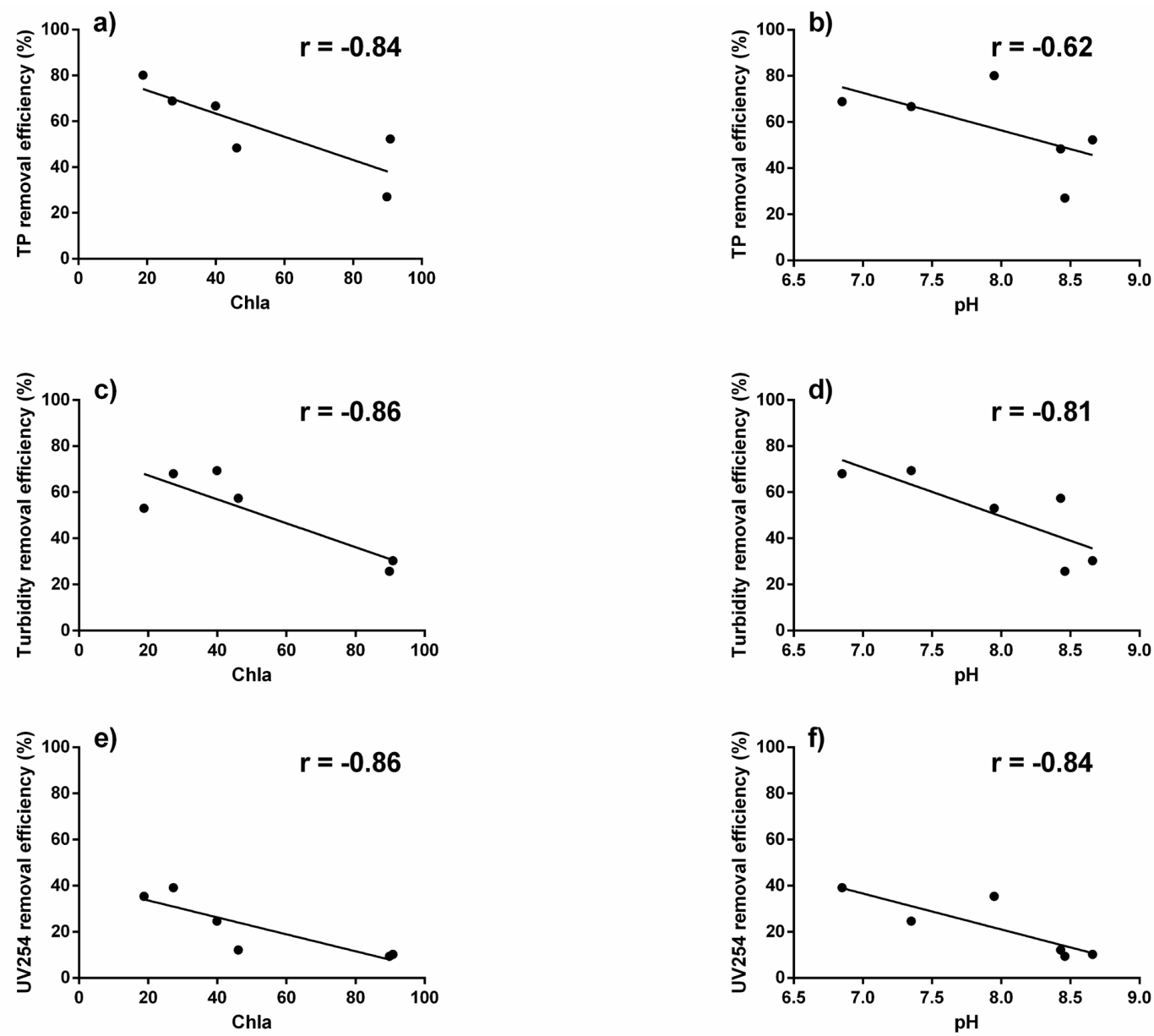

Figure 3. Correlations between chlorophyll-a concentration and $\mathrm{pH}$ with total phosphorus (TP), turbidity and $\mathrm{UV}_{254}$ removal efficiency (\%) based on the dose of $4 \mathrm{mg} \mathrm{Al} \mathrm{L}^{-1}$.

has been reported to affect coagulation performance of PAC (Yang et al., 2010). In the maximal PAC performance $\mathrm{pH}$ was found to be around the neutral (Hu et al., 2006; De Julio et al., 2010). Coagulation is favorable for a $\mathrm{pH}$ range of 6.0-7.0 due to presence of positively charged $\mathrm{Al}$ species promoting flock formation (Pernitsky \& Edzwald, 2006) which determines the coagulation performance (Yan et al., 2008a). The dose of $4 \mathrm{mg} \mathrm{Al} . \mathrm{L}^{-1}$ resulted in $\mathrm{pH}>8.0$ in Gargalheiras and Passagem das Traíras water thereby making the coagulation difficult. It has been suggested that high alkaline waters requires a higher PAC dose to achieve $\mathrm{pH}$ values favorable to coagulation (Hu et al., 2006).

The coagulation process induces the formation of flocks with differents size, charge and density, factors that influence directly in flock sedimentation. Flocks formed by algae cells have low density making them difficult to settle (Edzwald, 1993; Henderson et al., 2008a). Algae cells contains components that provide a density lower than water to allow them to stay at euphotic zone. Lipid accumulation, mucilage production, ionic regulation and gas vesicules are components of algal cell to avoid sedimentation (Reynolds, 2006). Extracellular and surface-retained organic matter produced by algae are reported to inhibit floc formation (Henderson et al., 2008b, 2010). Lipopolysaccharide on cell surface of Microcystis aeruginosa produced by the excess of growth exhibited inhibitory effects on PAC coagulation (Takaara et al., 2010), which can be one important cause of the increase in coagulant demand in algae-rich waters (Takaara et al., 2007). Also the flocculation process is negatively affected by the presence of dissolved organic matter present in the water (Edzwald, 1993), particularly humic susbtances. Humic substances are highly negatively charged (Yan et al., 2008a), which increases with increasing the $\mathrm{pH}$ and by adsorbing onto the surfaces of natural particles (Pernitsky \& Edzwald, 2006). Maximal $\mathrm{UV}_{254}$ removal was observed to be found around pH 6.0 (Yan et al., 2008b). The aquatic 
humic substances form complexes with dissolved aluminium species which are removed by adsorbing onto a solid, making the coagulation difficult in waters with both algae and humic susbtances (Pernitsky \& Edzwald, 2006).

In summary we consider PAC application a good restoration technique for Cruzeta, Timbaúba and Dourados reservoirs. Addition of polyaluminium chloride is a potential tool for water quality improvement of eutrophic shallow lakes in Brazilian semiarid region but its efficiency depends on the $\mathrm{pH}$ and particulate and dissolved organic matter concentration in the lake or reservoir water.

\section{Acknowledgements}

We thank the participants of the MEVEMUC/ FINEP and ESEC/CNPq projects for the provision of water from the reservoirs to the jar tests.

\section{References}

ARAÚJO, F., BECKER, V. and ATTAYDE, J.L. Shallow lake restoration and water quality management by the combined effects of polyaluminium chloride addition and benthivorous fish removal: a field mesocosm experiment. Hydrobiologia, 2016, 778(1), 243-252. http://dx.doi.org/10.1007/s10750-015-2606-5.

CHEN, J. and LUAN, Z. Enhancing phosphate removal by coagulation using polyelectrolytes and red mud. Fresenius Environmental Bulletin, 2010, 19(10), 2200-2204.

COOKE, G.D., WELCH, E.B., PETERSON, S.A. and NICHOLS, S.A. 2005. Restoration and management of lakes and reservoirs. Boca Raton: CRC Press.

DE JULIO, M., FIORAVANTE, D.A., DE JULIO, T.S., OROSKI, F.I. and GRAHAM, N.J.D. A methodology for optimising the removal of cyanobacteria cells from a brazilian eutrophic water. Brazilian Journal of Chemical Engineering, 2010, 27(1), 113-126. http://dx.doi.org/10.1590/S010466322010000100010

EDZWALD, J.K. Coagulation in drinking water treatment: particles, organics and coagulants. Water Science and Technology, 1993, 27(11), 21-35. http:// dx.doi.org/10.2166/wst.1993.0261.

EGEMOSE, S., DE VICENTE, I., REITZEL, K., FLINDT, M.R., ANDERSEN, F.Ø., LAURIDSEN, T.L., SØNDERGAARD, M., JEPPESEN, E., JENSEN, H.S. and PRAIRIE, Y. Changed cycling of P, N, Si, and DOC in Danish Lake Nordborg after aluminum treatment. Canadian Journal of Fisheries and Aquatic Sciences, 2011, 68(5), 842-856. http:// dx.doi.org/10.1139/f2011-016.

GAO, B., CHU, Y., YUE, Q., WANG, B. and WANG, S. Characterization and coagulation of a polyaluminum chloride (PAC) coagulant with high
Al 13 content. Journal of Environmental Management, 2005, 76(2), 143-147. http://dx.doi.org/10.1016/j. jenvman.2004.12.006. PMid:15939126.

HENDERSON, R., PARSONS, S.A. and JEFFERSON, $B$. The impact of algal properties and pre-oxidation on solid-liquid separation of algae. Water Research, 2008a, 42(8-9), 1827-1845. http://dx.doi.org/10.1016/j. watres.2007.11.039. PMid:18261761.

HENDERSON, R.K., BAKER, A., PARSONS, S.A. and JEFFERSON, B. Characterisation of algogenic organic matter extracted from cyanobacteria, green algae and diatoms. Water Research, 2008b, 42(13), 3435-3445. http://dx.doi.org/10.1016/j. watres.2007.10.032. PMid:18499215.

HENDERSON, R.K., PARSONS, S.A. and JEFFERSON, B. The impact of differing cell and algogenic organic matter (AOM) characteristics on the coagulation and flotation of algae. Water Research, 2010, 44(12), 3617-3624. http://dx.doi. org/10.1016/j.watres.2010.04.016. PMid:20462626.

HU, C., LIU, H., QU, J., WANG, D. and RU, J. Coagulation behavior of aluminum salts in eutrophic water: significance of $\mathrm{Al} 13$ species and $\mathrm{pH}$ control. Environmental Science \& Technology, 2006, 40(1), 325-331. http://dx.doi.org/10.1021/es051423+. PMid:16433368.

JANČULA, D. and MARŠÁLEK, B. Seven years from the first application of polyaluminium chloride in the Czech Republic - effects on phytoplankton communities in three water bodies. Chemistry and Ecology, 2012, 28(6), 535-544. http://dx.doi.org/1 0.1080/02757540.2012.696616.

JESPERSEN, A.M. and CHRISTOFFERSEN, K. Measurements of chlorophyll a from phytoplankton using ethanol as extraction solvent. Archives of Hydrobiologia, 1988, 109, 445-454.

JIANG, J.Q. and GRAHAM, N.J.D. Pre-polymerised inorganic coagulants and phosphorus removal by coagulation - A review. Water S.A., 1998, 24(3), 237-244.

LEENHEER, J.A. and CROUÉ, J.P. Peer reviewed: characterizing aquatic dissolved organic matter. Environmental Science and Technology, 2003, 37(1): 18A-26A.

LEWANDOWSKI, J., SCHAUSER, I. and HUPFER, $M$. Long term effects of phosphorus precipitations with alum in hypereutrophic Lake $S$ usser. Water Research, 2003, 37(13), 3194-3204. http:// dx.doi.org/10.1016/S0043-1354(03)00137-4. PMid:14509707.

LOPATA, M. and GAWROŃSKA, H. Phosphorus immobilization in Lake Głęboczek following treatment with polyaluminum chloride. Oceanological and Hydrobiological Studies, 2008, 37(2), 99-105. http://dx.doi.org/10.2478/v10009-007-0046-x. 
MURPHY, J.A.M.E.S.; RILEY, J.P. A modified single solution method for the determination of phosphate in natural waters. Analytica Chimica Acta, 1962, 27, 31-36. https://doi.org/10.1016/ S0003-2670(00)88444-5.

NOYMA, N.P., MAGALHÃES, L., FURTADO, L.L., MUCCI, M., VAN OOSTERHOUT, F., HUSZAR, V.L.M., MARINHO, M.M. and LÜRLING, M. Controlling cyanobacterial blooms through effective flocculation and sedimentation with combined use of flocculants and phosphorus adsorbing natural soil and modified clay. Water Research, 2015, 97, 26-38. PMid:26706124.

PERNITSKY, D.J. and EDZWALD, J.K. Selection of alum and polyaluminum coagulants: principles and applications. Journal of Water Supply: Research \& Technology - Aqua, 2006, 55(2), 121-141. http:// dx.doi.org/10.2166/aqua.2006.062.

REITZEL, K., HANSEN, J., ANDERSEN, F.Ø., HANSEN, K.S. and JENSEN, H.S. Lake restoration by dosing aluminum relative to mobile phosphorus in the sediment. Environmental Science \& Technology, 2005, 39(11), 4134-4140. http://dx.doi. org/10.1021/es0485964. PMid:15984792.

REITZEL, K., HANSEN, J., JENSEN, H.S., ANDERSEN, F.Ø. and HANSEN, K.S. Testing aluminum addition as a tool for lake restoration in shallow, eutrophic Lake Sønderby, Denmark. Hydrobiologia, 2003, 506(1-3), 781-787. http://dx.doi. org/10.1023/B:HYDR.0000008624.54844.2d.

REYNOLDS, C.S. 2006. Ecology of phytoplankton. Cambridge: Cambridge University Press, 2006. http://dx.doi.org/10.1017/CBO9780511542145.

SØNDERGAARD, M., JENSEN, J.P. and JEPPESEN, E. Role of sediment and internal loading of phosphorus in shallow lakes. Hydrobiologia, 2003, 506(1-3), 135-145. http://dx.doi.org/10.1023/ B:HYDR.0000008611.12704.dd.

SØNDERGAARD, M., JEPPESEN, E., JENSEN, J.P. and LAURIDSEN, T. Lake restoration in Denmark. Lakes and Reservoirs: Research and Management, 2000, 5(3), 151-159. http://dx.doi.org/10.1046/j.14401770.2000.00110.x.

SPEARS, B.M., LÜRLING, M., YASSERI, S., CASTRO-CASTELLON, A.T., GIBBS, M., MEIS, S., MCDONALD, C., MCINTOSH, J., SLEEP, D. and VAN OOSTERHOUT, F. Lake responses following lanthanum-modified bentonite clay $\left(\right.$ Phoslock $^{\circ}$ ) application: an analysis of water column lanthanum data from 16 case study lakes. Water Research, 2013, 47(15), 5930-5942. http://dx.doi.org/10.1016/j.watres.2013.07.016. PMid:23911225.

TAKAARA, T., SANO, D., KONNO, H. and OMURA, T. Cellular proteins of Microcystis aeruginosa inhibiting coagulation with polyaluminum chloride. Water Research, 2007, 41(8), 1653-1658. http://dx.doi.org/10.1016/j.watres.2007.01.035. PMid:17353025.

TAKAARA, T., SANO, D., MASAGO, Y. and OMURA, T. Surface-retained organic matter of Microcystis aeruginosa inhibiting coagulation with polyaluminum chloride in drinking water treatment. Water Research, 2010, 44(13), 3781-3786. http://dx.doi.org/10.1016/j.watres.2010.04.030. PMid:20570314.

THORNTON, J.A.; RAST, W. A test of hypotheses relating to the comparative limnology and assessment of eutrophication in semi-arid man-made lakes. In: M. STRAŠKRABA, J.G. TUNDISI and A. DUNCAN, eds. Comparative reservoir limnology and water quality management. Developments in hydrobiology. Dordrecht: Springer, 1993, vol. 77. https://doi.org/10.1007/978-94-017-1096-1_1.

VALDERRAMA, J. C. The simultaneous analysis of total nitrogen and total phosphorus in natural waters. Marine Chemistry, 1981, 10(2), 109-122. https://doi.org/10.1016/0304-4203(81)90027-X.

VAN BENSCHOTEN, J.E. and EDZWALD, J.K. Chemical aspects of coagulation using aluminum salts-II. coagulation of fulvic acid using alum and polyaluminum chloride. Water Research, 1990, 24(12), 1527-1535. http://dx.doi.org/10.1016/00431354(90)90087-M.

VAN HULLEBUSCH, E., DELUCHAT, V., CHAZAL, P.M., and BAUDU, M. Environmental impact of two successive chemical treatments in a small shallow eutrophied lake: Part I. Case of aluminium sulphate. Environmental Pollution, 2002, 120(3), 617-626. https://doi.org/10.1016/S02697491(02)00192-6.

WELCH, E.B. and COOKE, G.D. Effectiveness and longevity of phosphorus inactivation with alum. Lake and Reservoir Management, 1999, 15(1), 5-27. http:// dx.doi.org/10.1080/07438149909353948.

WELCH, E.B. and SCHRIEVE, G.D. Alum treatment effectiveness in and longevity in shallow lakes. In: E. Mortensen, E. Jeppesen, M. Sondergaard and L. K. Nielsen, eds. Nutrient dynamics and biological structure in shallow freshwater and brackish lakes. Netherlands: Springer, 1994, pp. 423-431. http:// dx.doi.org/10.1007/978-94-017-2460-9_37.

YAN, M., WANG, D., NI, J., QU, J., CHOW, C.W.K. and LIU, H. Mechanism of natural organic matter removal by polyaluminum chloride: effect of coagulant particle size and hydrolysis kinetics. Water Research, 2008a, 42(13), 3361-3370. http://dx.doi.org/10.1016/j.watres.2008.04.017. PMid: 18519148.

YAN, M., WANG, D., YU, J., NI, J., EDWARDS, M. and QU, J. Enhanced coagulation with polyaluminum chlorides: role of $\mathrm{pH} /$ alkalinity and speciation. Chemosphere, 2008b, 71(9), 1665-1673. http:// 
dx.doi.org/10.1016/j.chemosphere.2008.01.019. PMid:18328534.

YANG, Z., GAO, B. and YUE, Q. Coagulation performance and residual aluminum speciation of $\mathrm{Al} 2(\mathrm{SO} 4) 3$ and polyaluminum chloride (PAC) in Yellow River water treatment. Chemical Engineering
Journal, 2010, 165(1), 122-132. http://dx.doi. org/10.1016/j.cej.2010.08.076.

Received: 17 November 2016

Accepted: 01 August 2018 